\title{
Molecular characterization of idiA and adjacent genes in the cyanobacteria Synechococcus sp. strains PCC 6301 and PCC 7942
}

\author{
Klaus-Peter Michel, ${ }^{1}$ Frauke Krüger, ${ }^{1}$ Alfred Pühler $^{2}$ \\ and Elfriede K. Pistorius ${ }^{1}$
}

Biologie VIII:

Zellphysiologie 1 and

Biologie VI: Genetik²,

Universität Bielefeld,

33501 Bielefeld, Germany
Author for correspondence: Elfriede K. Pistorius. Tel: +49521 1065601. Fax: +49521 1066410. e-mail : e.pistorius@ $@$ biologie.uni-bielefeld.de

IdiA (iron-deficiency-induced protein A) is a protein expressed at highly elevated levels in Synechococcus sp. strains PCC 6301 and PCC 7942 under Feor Mn-limiting growth conditions. Besides being similar to two bacterial Febinding proteins, SfuA and FbpA, IdiA shows similarity to two ORFs (s/r0513 and s/r1295) of Synechocystis sp. PCC 6803. Northern blot analysis detected one transcript of about 1300 nt in RNA extracted from Synechococcus sp. PCC 6301 and PCC 7942 grown under Fe deficiency. The intensity of this transcript was considerably reduced in Fe-sufficient culture. It could be further shown that the regulation of IdiA expression is at the transcriptional level and that transcription and translation of IdiA are closely linked. Primer extension analysis indicated a single transcriptional start site $193 \mathrm{nt}$ upstream of the first presumed translational start codon. Moreover, molecular characterization of the entire $5.8 \mathrm{~kb}$ chromosomal HindIII DNA fragment carrying the idiA gene from Synechococcus Sp. PCC 6301 led to the identification of six long ORFs in addition to idiA. The two genes adjacent to idiA, and dpsA located $2018 \mathrm{nt}$ downstream of idiA, were insertionally inactivated in Synechococcus sp. PCC 7942 and the corresponding mutants were partially characterized. These experiments provide evidence that the gene products of idiB, located immediately downstream of idiA, and of dpsA are involved in the activation of IdiA expression, since the absence of each of these two gene products prevents the greatly elevated expression of IdiA under nutrient deficiency.

Keywords: cyanobacteria, Synechococcus sp., idiA, transcript analysis, transcription factor

\section{INTRODUCTION}

Iron is an essential redox component in a great number of enzymes and protein complexes and thus iron deficiency has a profound effect on the physiology of cyanobacteria and other organisms (for reviews, see: Straus, 1994; Ferreira \& Straus, 1994; Carr \& Mann, 1994). It is well documented that in cyanobacteria Fe deficiency causes substantial changes in the ultrastructure of the thylakoid membranes, a decrease of

This paper is dedicated to Professor Dr Birgit Vennesland on the occasion of her 85th birthday.

Abbreviations: DIG, digoxigenin; PS I and II, photosystem I and II.

The GenBank accession number for the sequence of the region containing idiA is $\mathrm{Z48754}$. pigment content and a reduction of the photosynthetic activities. Under Fe limitation a new chlorophyll protein complex, called CPVI-4, is formed in Synechococcus PCC 7942 (Riethman \& Sherman, 1988a, b). CPVI-4 might function in optimizing light energy transfer to the reaction centres or serve as a chlorophyll sink under $\mathrm{Fe}$ deficiency when other major chlorophyll-protein complexes are greatly degraded. It has also been shown for several cyanobacteria that the Fe-repressible isiAB operon is expressed, encoding a CP43-like chlorophyllbinding protein (IsiA) and a replacement for ferredoxin called flavodoxin (IsiB) (Laudenbach \& Straus, 1988; Leonhardt \& Straus, 1992, 1994). Subsequently, IsiA was identified to be a component of CPVI-4 in Synechococcus PCC 7942 (Burnap et al., 1993). In addition, two more Fe-regulated genes have been identified in Synecho- 
coccus PCC 7942: irpA encoding a protein located in the cytoplasmic membrane and presumably involved in $\mathrm{Fe}$ acquisition or storage (Reddy et al., 1988), and mapA encoding a protein of unknown function (Webb et al., 1994). Based on a nucleotide sequence evaluation by Straus (1994), it seems that all cyanobacterial Fe-stressinduced genes investigated so far contain operator sequences related to the Fur binding consensus sequence. Moreover, the search for a corresponding gene has led to the identification of a homologue of the 'ferric iron uptake regulation gene', fur, in Synechococcus PCC 7942 (Ghassemian \& Straus, 1996).

Besides $\mathrm{Fe}$, oxygenic photosynthetic organisms have an absolute requirement for manganese, an essential component in the water-oxidizing complex of photosystem II (PS II). Although substantial information exists in the literature on how $\mathrm{Mn}$ is incorporated into the wateroxidizing complex of PS II by a light-driven process (for review, see Debus, 1992), very little information is available on $\mathrm{Mn}$ metabolism in the oxygenic photosynthetic cell. Bartsevich \& Pakrasi $(1995,1996)$ identified genes encoding an ABC transporter complex involved in Mn uptake in the cyanobacterium Synechocystis PCC 6803. However, it is unclear whether the transporter is located in the cytoplasm and/or the thylakoid membrane. Another problem that has also received little attention is related to the question of how the intrathylakoid space of a cyanobacterium is sufficiently supplied with $\mathrm{Mn}$ under conditions of $\mathrm{Fe}$ limitation. Under such conditions, elevated expression of Fe-binding proteins in the cytoplasm might lead to trapping of $\mathrm{Mn}$ in the cytoplasm, since practically all $\mathrm{Fe}-$ binding proteins characterized so far also bind $\mathrm{Mn}$. Thus, a rather complex interrelationship must exist between $\mathrm{Fe}$ and $\mathrm{Mn}$ metabolism, especially in an oxygenic prokaryotic cell with no separate organelles.

In previous publications (Michel \& Pistorius, 1992; Michel et al., 1996) we reported a protein called IdiA (iron-deficiency-induced protein A) that becomes expressed in greatly elevated levels in Synechococcus PCC 6301 and PCC 7942 under Fe deficiency and under Mn deficiency. On the basis of the derived amino acid sequence, processed IdiA has a calculated molecular mass of $35009 \mathrm{Da}$ that agrees well with the published apparent molecular mass of $34 \mathrm{kDa}$ for the isolated protein. Biochemical fractionation procedures and immunocytochemical investigations provided evidence that IdiA is located intracellularly and mainly associated with the cytoplasmic side of thylakoid membranes (Michel et al., 1998). The gene encoding IdiA in Synechococcus PCC 6301 was identified, sequenced and partially analysed. Subsequent construction of an IdiAfree Synechococcus PCC 7942 mutant revealed that in the absence of IdiA the cells could not tolerate mild Fe or Mn deficiency as wild-type cells could. Measurements of PS II and PS I activities in the IdiA-free mutant provided evidence that mainly PS II was damaged under nutrientdeficient conditions. Thus, IdiA is obviously a protein optimizing and/or protecting PS II under Fe and/or Mn deficiency in a direct or indirect fashion.
In this study, an extended characterization of $i d i A$ in Synechococcus PCC 6301 was performed and the DNA region surrounding idiA in Synechococcus PCC 6301 and PCC 7942 was analysed.

\section{METHODS}

Origin of cyanobacteria, growth conditions and French press treatment. Synechococcus sp. strain PCC 6301 (SAUG B14021) and Synechococcus sp. strain PCC 7942 were obtained from the Sammlung von Algenkulturen der Universität Göttingen, Göttingen, Germany, and from the Pasteur Culture Collection of Cyanobacterial strains, Paris, France, respectively.

For regular growth conditions, cyanobacteria were grown in gas wash bottles containing $250 \mathrm{ml}$ medium in a stream of $2 \%$ (v/v) $\mathrm{CO}_{2}$ in air (growth for $2 \mathrm{~d}$, inoculum $60 \mu \mathrm{l}$ cells). Synechococcus PCC 6301 was grown at $30^{\circ} \mathrm{C}$ in the medium of Kratz \& Myers (1955) with slight modifications as described by Pistorius et al. (1989). Synechococcus PCC 7942 was grown in BG11 medium (Rippka, 1988) at $30^{\circ} \mathrm{C}$. For growth under nutrient-deficient conditions, cells were grown for several cycles under regular growth conditions, then harvested and, after washing with distilled water, were subsequently transferred into medium from which $\mathrm{Mn}$ or $\mathrm{Fe}$ was omitted. Growth of both Synechococcus strains on agar plates was achieved in BG11 medium containing $1 \%(\mathrm{w} / \mathrm{v})$ agar (bacteriological grade; Gibco-BRL). Where indicated, antibiotics were added at the following concentrations $\left(\mathrm{mg} \mathrm{l}^{-1}\right)$ : kanamycin, 25; ampicillin (Ap), 10; spectinomycin (Sp), 25.

For preparation of French press extracts used for Western blotting experiments, Synechococcus cells were harvested by centrifugation, washed once with $10 \mathrm{mM}$ sodium phosphate buffer, $\mathrm{pH} 7 \cdot 0$, and then resuspended in the same buffer to give a cell density of $100 \mu \mathrm{l}$ cells $\mathrm{ml}^{-1}$. This cell suspension was passed twice through a pre-chilled French press at $137.9 \mathrm{MPa}$. Unbroken cells were removed by centrifugation at $4000 \mathrm{~g}$ for $5 \mathrm{~min}$. French press extracts for PS I and PS II activity measurements were made in a buffer containing $50 \mathrm{mM}$ HEPES/ $\mathrm{NaOH}, \mathrm{pH} 6 \cdot 5,50 \mathrm{mM} \mathrm{CaCl}_{2}$ and $400 \mathrm{mM}$ sucrose.

Escherichia coli strains DH5 $\mathrm{mcr}^{-}$(Grant et al., 1990) and SCS110 (Stratagene) were cultivated at $37^{\circ} \mathrm{C}$ in LBG medium (Sambrook et al., 1989) or on PA agar plates containing $17.5 \mathrm{~g}$ antibiotic medium no. 3 (assay broth, Oxoid) and $16 \mathrm{~g}$ bacteriological agar (Oxoid) in 11 distilled water. Where indicated, antibiotics were added at the following concentrations ( $\mathrm{mg} \mathrm{l}^{-1}$ ): ampicillin, 150; kanamycin, 50; spectinomycin, 100.

Biochemical determinations. PS I and PS II activities were determined as described by Michel et al., 1996. Chlorophyll was estimated according to Grimme \& Boardman (1972), phycocyanin and allophycocyanin according to Tandeau de Marsac \& Houmard (1988) and protein according to Smith et al. (1985). SDS-PAGE was performed according to Laemmli (1970) or Schägger \& von Jagow (1987). Protein samples for SDS-PAGE (10\% polyacrylamide gel) were denatured either at $70{ }^{\circ} \mathrm{C}$ for $15 \mathrm{~min}$ (Laemmli system) or $5 \mathrm{~min}$ at $100^{\circ} \mathrm{C}$ (Tris-Tricine system). Protein $(15$ or $30 \mu \mathrm{g}$ ) was applied in each lane (Figs 3 or 7 , respectively). Immunoblotting was done as described by Michel \& Pistorius (1992) by transferring proteins to nitrocellulose (Schleicher \& Schüll, BA 85) and using previously raised anti-IdiA antiserum at a dilution of 1:15000. (Michel \& Pistorius, 1992).

DNA isolation, cloning and sequencing. Plasmids pSVB30 (Arnold \& Pühler, 1988), pNEB193 (New England Biolabs) 
and pKPM24 (Michel et al., 1996) were used as basic tools for genetic engineering. pKPM24 is a derivative of pSVB30 containing a $5.8 \mathrm{~kb}$ HindIII fragment of genomic Synechococcus PCC 6301 DNA carrying idiA (Michel et al., 1996).

Total DNA from Synechococcus PCC 7942 and from the corresponding mutants was isolated by the Sarkosyl method and purified by the phenol extraction procedure (William, 1988; Sambrook et al., 1989).

Cloning procedures, Southern blotting and other recombinant DNA techniques were done as described in Sambrook et al. (1989). Sequencing of the pKPM24 insert was performed by constructing corresponding overlapping subclones using the Pharmacia double-stranded Nested Deletion Kit and a Pharmacia ALFexpress DNA Sequencer. The nucleotide sequence of the $5.8 \mathrm{~kb}$ DNA fragment was determined by the dideoxy chain-termination method. The enzymes used in this study were purchased from Boehringer Mannheim, Pharmacia, Amersham and USB.

Computer analysis. Nucleic acid sequences were analysed using the Staden software package (Staden, 1986). The deduced amino acid sequences were analysed using two different programs: PC/GENE (IntelliGenetics Release 6.8, 1993) and XPIP (Staden, 1986). Homology searches were done with the BLAST algorithm by Altschul et al. (1990) in the SWISS-PROT, EMBL, PIR, GenBank and CyanoBase databases.

Oligonucleotide synthesis and PCR. The following oligonucleotides used for primer extension assays were designed on the basis of certain DNA regions upstream and downstream of the $i d i A$ start codon using the selection criteria of the program Primer Design version 2.2 (Scientific \& Educational Software): KPM1 (20mer), Cy5'-GATTGTCGGTGTTGTAGTGC-3' (2307-2288); KPM2 (21mer), Cy5'-GACTTCACCTTCAGCAGCTTC-3' (2270-2250) ; KPM3 (23mer), Cy 5'-GCGGCTGCCTTCACTCTTGAGAC-3' (2408-2386); KPM4 (20mer), Cy5'-CACTCTTGGTATCGGCGCCT-3' (2078-2059); KPM5 (20mer), Cy5'-TAATAGCGTTCCGGCGAGAG-3' (2216-2 197); KPM6 (17mer), Cy 5'-CGCACCGCGATAACTCA-3' (2031-2015) (Cy, indodicarbocyanine).

The oligonucleotides used to generate a PCR-derived idiA fragment (2256-3241) for all types of labelling experiments were designed using the program Oligo version 4.0 (Rychlik \& Rhoads, 1989): IdiA00A (22mer), P5'-GCTGAAGGTGAAGTCAATTTGT-3' (plus strand: 2256-2277); IdiA00B (21 mer), P5'-TGAAGTGATCCAATAACGTCT-3' (minus strand: 3221-3241). All oligonucleotides were manufactured by Pharmacia Biotech.

PCR was performed with pKPM24 as template using Pwo DNA polymerase (Boehringer Mannheim) according to the manufacturer's recommendations.

RNA isolation, Northern blotting and primer extension assay. RNA was isolated from Synechococcus cultures at various growth phases using a modified hot-phenol method according to Reddy et al. (1990). For hybridization experiments, the RNA was denatured for $10 \mathrm{~min}$ at $68^{\circ} \mathrm{C}$ with a buffer containing formamide and formaldehyde $[20 \mathrm{mM} \mathrm{MOPS} /$ $\mathrm{NaOH}, \mathrm{pH} 7 \cdot 0,5 \mathrm{mM}$ sodium acetate, $1 \mathrm{mM}$ disodium EDTA, $50 \%(\mathrm{v} / \mathrm{v})$ formamide, $16 \%(\mathrm{v} / \mathrm{v})$ formaldehyde]. After adding stop solution $[20 \mathrm{mM}$ disodium EDTA, $95 \%$ $(\mathrm{v} / \mathrm{v})$ formamide, $0.1 \%$ bromophenol blue, $0.1 \%$ xylene cyanole], the RNA $(10 \mu \mathrm{g})$ was separated in a formaldehyde agarose gel system (1.3 g agarose in $73 \mathrm{ml}$ dimethyldicarbonate-treated double-distilled $\mathrm{H}, \mathrm{O}, 10 \mathrm{ml} 200 \mathrm{mM}$
MOPS/ $\mathrm{NaOH}, \mathrm{pH} 7 \cdot 0,50 \mathrm{mM}$ sodium acetate, $10 \mathrm{mM}$ disodium EDTA, $17 \mathrm{ml}$ formaldehyde). After transfer to a nylon membrane (Hybond-N + ; Amersham), the probes were hybridized with an $\left[\alpha^{-32} \mathrm{P}\right] \mathrm{dATP}$-labelled $986 \mathrm{bp}$ idiA PCR fragment (2256-3241) in Church buffer [7\% (w/v) SDS, $50 \%$ $(\mathrm{v} / \mathrm{v})$ formamide, $5 \times \mathrm{SSC}(75 \mathrm{mM}$ sodium citrate, $\mathrm{pH} 7 \cdot 0$, $750 \mathrm{mM} \mathrm{NaCl}$ ), $2 \%(\mathrm{w} / \mathrm{v})$ blocking reagent (Boehringer Mannheim), $50 \mathrm{mM}$ sodium phosphate buffer, $\mathrm{pH} 7 \cdot 0,0 \cdot 1 \%$ $(\mathrm{v} / \mathrm{v})$ laurylsarcosine). The labelling reaction was done with the Random Primed DNA Labelling Kit (Boehringer Mannheim), according to the manufacturer's recommendation. Labelled fragments were cleaned by centrifugation through a Sephadex G25 column. Alternatively, the idiA PCR fragment was labelled with digoxigenin (DIG)-dUTP using the DIG DNA Labelling and Detection Kit (Boehringer Mannheim). RNA markers were from New England Biolabs.

The primer extension assay was carried out according to Katzen et al. (1996). The annealing mix contained $10 \mu \mathrm{g}$ RNA in a volume of $6 \mu \mathrm{l}, 20 \mathrm{pmol} \mathrm{Cy5}$ labelled primer (Pharmacia Biotech) in $1 \mu \mathrm{l}$ dimethyldicarbonate-treated double-distilled $\mathrm{H}_{2} \mathrm{O}, 2 \mu \mathrm{l} 5 \times$ annealing buffer $(10 \mathrm{mM}$ Tris/ $\mathrm{HCl}, \mathrm{pH} 7 \cdot 9$, $1.25 \mathrm{M} \mathrm{KCl}, 1 \mathrm{mM}$ EDTA) and $1 \mu \mathrm{l}$ RNase inhibitor $(1$ unit $\mu \mathrm{l}^{-1}$; Pharmacia). The annealing reaction was carried out for $2 \mathrm{~h}$ at 37,42 and $50^{\circ} \mathrm{C}$. For the extension reaction, $10 \mu \mathrm{l}$ annealing mix, $23 \mu \mathrm{l} \mathrm{PE} \mathrm{mix}(1 \mu \mathrm{l} 1 \mathrm{M}$ dithiothreitol and $6.5 \mu \mathrm{l}$ $10 \mathrm{mM}$ dNTP mix in $192.5 \mu \mathrm{l} 20 \mathrm{mM}$ Tris/ $\mathrm{HCl}, \mathrm{pH} 8 \cdot 3$, $10 \mathrm{mM} \mathrm{MgCl}_{2}$ ) and $1 \mu \mathrm{l}$ SuperScript $\mathrm{RNase} \mathrm{H}^{-}$reverse transcriptase (200 units $\mu l^{-1}$; Gibco-BRL) were incubated for $45 \mathrm{~min}$ at $37^{\circ} \mathrm{C}$. The products were pelleted by centrifugation for $15 \mathrm{~min}$ at $4^{\circ} \mathrm{C}$ after precipitation by adding $300 \mu \mathrm{l}$ ethanol and storing for $20 \mathrm{~min}$ at $-70{ }^{\circ} \mathrm{C}$. The resulting pellet was resuspended in $7 \cdot 5 \mu \mathrm{l}$ TE buffer $(10 \mathrm{mM}$ Tris $/ \mathrm{HCl}, \mathrm{pH} 7 \cdot 5$, $1 \mathrm{mM}$ disodium EDTA) and $6 \mu \mathrm{l}$ stop solution from the AutoRead Sequencing Kit (Pharmacia).

Construction of mutants in Synechococcus PCC 7942. The construction of mutants was performed by transforming wild-type cells of Synechococcus PCC 7942 according to Laudenbach \& Straus (1988) with the corresponding plasmids for insertional gene inactivation. All blunt-ended DNA fragments needed for this purpose were made using T4 DNA polymerase or Klenow enzyme (Boehringer Mannheim).

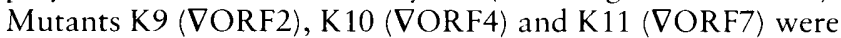
constructed by transforming wild-type cells with pKPM227, pKPM229 and pKPM230 (all derivatives of pKPM24), respectively. pKPM227 was constructed by incorporation of a

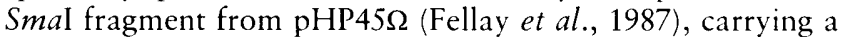
spectinomycin resistance cassette, into the blunt-ended single $K p n I$ site of pKPM24 at position 1397. pKPM229 carries the SmaI fragment cloned into the blunt-ended single ApaI site of pKPM24 at position 3882. pKPM230 also contains the Smal fragment cloned into the blunt-ended singular BstXI site of pKPM24 at position 5282. All other conditions were as described by Michel et al. (1996).

\section{RESULTS AND DISCUSSION}

\section{Nucleotide sequence analysis of a $5.8 \mathrm{~kb}$ Hind III chromosomal DNA fragment from Synechococcus PCC 6301 carrying idiA}

Plasmid pKPM24 (Michel et al., 1996) carrying $i d i A$ was derived from plasmid pSVB30 (Arnold \& Pühler, 1988) and contains a $5.8 \mathrm{~kb}$ chromosomal HindIII DNA fragment from Synechococcus PCC 6301. Previously, 


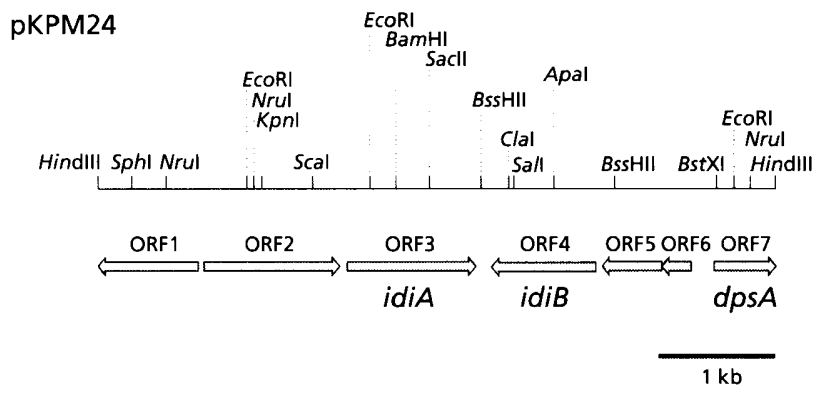

Fig. 1. Physical map of the $5763 \mathrm{bp}$ HindIII DNA fragment of Synechococcus PCC 6301 carrying idiA. pKPM24 is a derivative of pSVB30. Besides idiA (ORF3, 2121-3221), six additional long ORFs are located on this DNA fragment: ORF1, incomplete, 807-1; ORF2, 872-2017; ORF4 (idiB), 4090-3464; ORF5, 4747-4187; ORF6, 5004-4744; ORF7 (dpsA), incomplete, 5239-5763. The size and orientation of the genes are shown by the shaded arrows.

$2273 \mathrm{bp}$ had been sequenced. In this study the complete nucleotide sequence of both strands of the entire $5763 \mathrm{bp}$ DNA fragment (GC content $55.08 \mathrm{~mol} \%$ ) was determined and the physical map with the relevant restriction sites is shown in Fig. 1. Besides idiA (ORF3, 2121-3221), the $5.8 \mathrm{~kb}$ DNA fragment contains six additional long ORFs: two located upstream (ORFs 1 and 2) and four located downstream of idiA (ORFs 4-7).

Homology analysis of the identified ORFs revealed that the ORF1 (807-1) gene product shows extensive homology to LivH from E. coli (accession no. P08340; $33.09 \%$ identity, $21.56 \%$ conservative changes) (Landick \& Oxender, 1985; Nazos et al., 1986) and to BraD from Pseudomonas aeruginosa (accession no. P21627; 30.48\% identity, 22.68\% conservative changes) (Hoshino \& Kose, 1990). LivH (307 aa) as well as BraD (308 aa) are components required for the high-affinity branched chain amino acid transport system in the respective species. Both are hydrophobic proteins with six predicted transmembrane helices. In addition, ORF1 of Synechococcus PCC 6301 shows similarity to slr0949 of Synechocystis PCC 6803 which encodes a protein of 286 aa with a calculated molecular mass of $31133 \mathrm{Da}$ (55.02\% identity, $17 \cdot 84 \%$ conservative changes) (Cyano Base). Like LivH, BraD and Slr0949, the ORF1 product of Synechococcus PCC 6301 is a hydrophobic protein and contains six transmembrane helices. It has a potential cleavage site between aa 26 and 27 with either an ALA motif or an AA motif (Proteome Project, Cyano2Dbase; Sazuka \& Ohara, 1996) and is preceded by a possible ribosome-binding site (Shine-Dalgarno sequence) beginning at position 833 (GGAG) (Sazuka \& Ohara, 1996). ORF1 on pKPM24 is incomplete; the sequenced part encodes 269 aa. The hydrophobic nature of the ORF1 gene product in Synechococcus PCC 6301 clearly classifies this protein as an integral membrane protein. However, it is unknown whether this protein is located in the cytoplasmic membrane or in the thylakoid membrane.
ORF2 (872-2017) has a potential Shine-Dalgarno sequence at position 859 (GAGG), shows homology to sll1025 from Synechocystis PCC 6803 (33.86\% identity, $13.65 \%$ conservative changes) (CyanoBase) and encodes a protein of unknown function. Further evaluation of the derived amino acid sequence provides evidence that the $\mathrm{N}$-terminal region (890-906) of ORF2 has homology to a dinucleotide-binding domain with a GXGXXG motif (Wierenga et al., 1986). The highest level of homology was found to exist with the FAD-containing sarcosine oxidase from Bacillus sp. (accession no. D16521; Suzuki et al., 1994).

ORF4 (subsequently called idiB; 4090-3464) has a possible Shine-Dalgarno sequence at position 4102 (AGGA) and encodes a protein of 208 aa with a calculated molecular mass of $23237 \mathrm{Da}$ which has similarity to CysR from Synechococcus PCC 7942 (39.32\% identity and $12.14 \%$ conservative changes) (Nicholson \& Laudenbach, 1995). CysR in PCC 7942 encodes a polypeptide which is sulfur-regulated and which has homology to the DNA-binding regulatory proteins Fnr and Crp from E. coli (Unden \& Guest, 1985; Pastan \& Adhya, 1976) and FixK from Sinorhizobium meliloti (Batut et al., 1989). The greatest similarity between CysR and the regulatory proteins from enteric bacteria is in the helix-turn-helix motif which is directly involved in DNA binding (Brennan \& Matthews, 1989). ORF4 contains such a helix-turn-helix motif (A/G- $\mathrm{X}_{3}$ $\left.\mathrm{G}-\mathrm{X}_{5}-\mathrm{I} / \mathrm{V}\right)$, has high similarity to CysR over the whole sequence and preferentially resembles $\mathrm{NtcA}$ in its helix-turn-helix motif (Vega-Palas et al., 1992; Frias et al., 1993; Wei et al., 1993; Bradley \& Reddy, 1997). Thus, ORF4 might also be a DNA-binding protein (see below). The alignment of conserved sequences of this motif $(A, G$ and $I / V)$ is shown in Fig. 2. In addition ORF4 possesses a motif of the type SPXX at the N terminus (residues 23-26: SPTT). A similar motif is also found in CysR. Such a motif is common among transcriptional regulators of the helix-turn-helix type (Suzuki, 1989). The variable residues are most often S, $\mathrm{T}, \mathrm{A}, \mathrm{L}$ or $\mathrm{P}$ and the motif never lies in the helixturn-helix domain.

No amino acid sequence significantly similar to the proteins encoded by ORF5 (4747-4187) or ORF6 (5004-4744) was found in the NBRF or GenBank databases. ORF7 (5239-5763) from Synechococcus PCC 6301 , with a possible Shine-Dalgarno sequence at 5230, is identical to dpsA from Synechococcus PCC 7942 sequenced and characterized by Pena \& Bullerjahn (1995). The codon for the last amino acid of DpsA from PCC 6301 is not located on pKPM24. As stated by Pena \& Bullerjahn (1995), the Dps family of proteins are a diverse group of bacterial stress-induced polypeptides that bind DNA and likely confer resistance to peroxide damage during periods of oxidative stress and long-term nutrient limitation. The $\mathrm{C}$ terminus of DpsA from PCC 7942 has about $60 \%$ similarity to the $C$ terminus of bacterioferritin. It has been shown that the DpsA complex contains haem and has weak catalase activity in vitro. Moreover, it has been suggested that the protein 


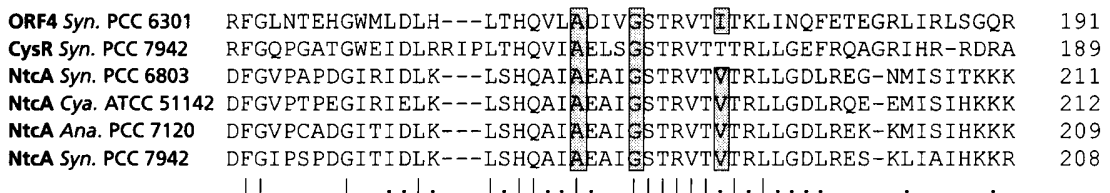

Helix Turn Helix

Fig. 2. Comparison of the ORF4 gene product (IdiB) from Synechococcus PCC 6301 with the regulatory and DNA-binding proteins CysR from Synechococcus PCC 7942 (accession no. P27369), NtcA from Synechocystis PCC 6803 (P33779), NtcA from Cyanothece ATCC 51142 (U80855), NtcA from Anabaena PCC 7120 (Q05061) and NtcA from Synechococcus PCC 7942 (P29283). The helix-turn-helix and putative DNA binding motif (underlined) is indicated. The typical, highly conserved amino acid residues of the helix-turn-helix motif are boxed. ' $\mid$ ' indicates identical amino acids; ' $\because$ ' indicates conservatively exchanged amino acids ( $A / S / T, D / E, N / Q, R / K, I / L / M N$ and $F / Y M N)$. Gaps were introduced into the sequences to maintain optimal alignment.

(a)

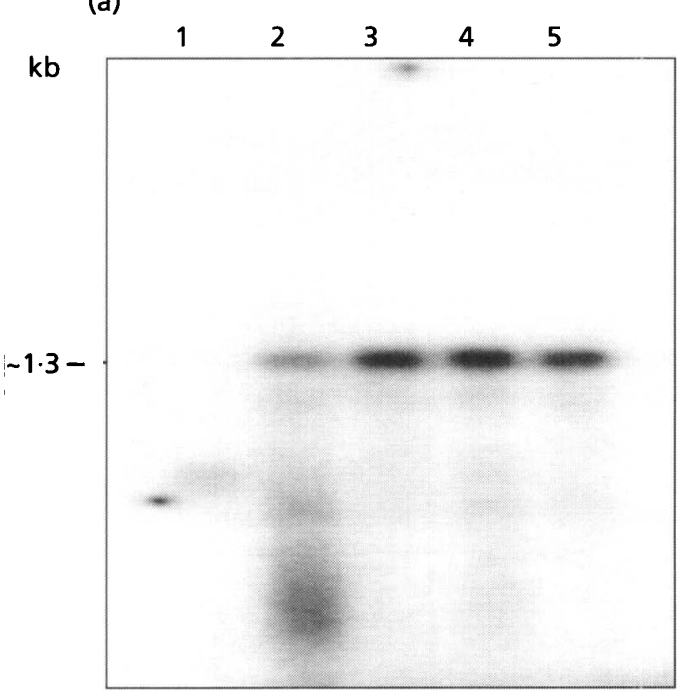

(b)

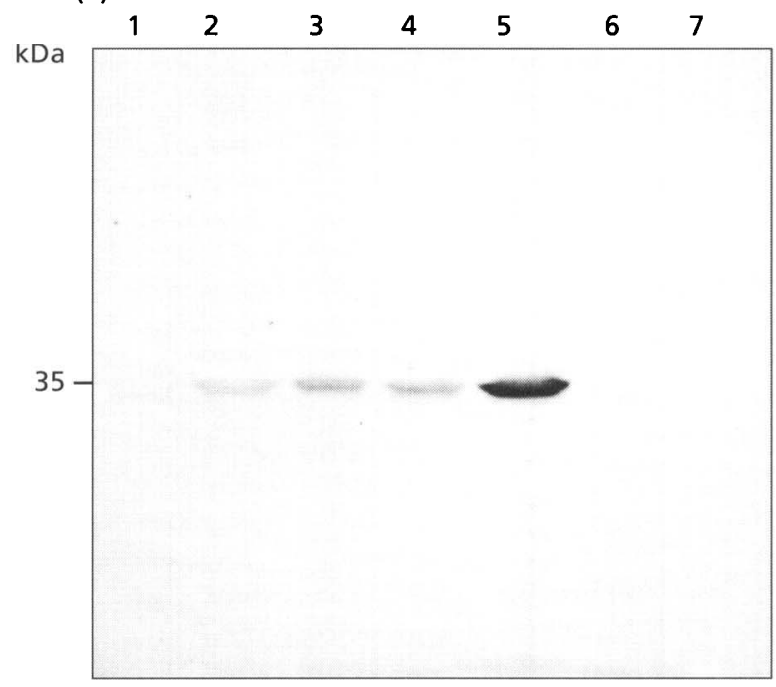

Fig. 3. Time course of idiA mRNA expression (a) and IdiA protein expression (b) under Fe deficiency in Synechococcus PCC 6301. idiA mRNA was detected by Northern blotting and IdiA protein by Western blotting. Synechococcus PCC 6301 cells were grown under Fe-sufficient growth conditions (Lanes 1) and then transferred with dilution $(60 \mu \mathrm{l}$ cells per $250 \mathrm{ml}$ medium) into medium containing no Fe. Cell samples were taken at different growth stages: $O D_{750}$ of 0.8 (lanes 2 ), 1.2 (lanes 3), 1.6 (lanes 4), and 2.0 (lanes 5). Synechococcus cells grown under Fe-deficient conditions $\left(\mathrm{OD}_{750}\right.$ of 2.0) in the presence of rifampicin (lane 6) or chloramphenicol (lane 7) [200 $\mu \mathrm{g}$ (ml medium) ${ }^{-1}$ each] were chosen as control.

may have a peroxide-consuming function when located on the chromosome and that this activity may be a necessary feature to handle the endogenous oxidative stresses associated with oxygenic photosynthesis.

\section{Nucleotide sequence analysis and extended homology analysis of idiA}

Previously, we assumed that idiA encoded a protein of 330 aa with a predicted molecular mass of $36167 \mathrm{Da}$ (Michel et al., 1996). Only 163 aa derived from the nucleotide sequence were verified by protein sequencing. On the basis of $\mathrm{N}$-terminal sequencing of the isolated IdiA protein, it could be concluded that the mature IdiA is a processed protein consisting of 321 aa with a calculated molecular mass of $35009 \mathrm{Da}$ (processing between two alanine residues). The calculated molecular mass of the processed protein agrees quite well with the apparent molecular mass of $34 \mathrm{kDa}$ determined by SDSPAGE. Due to the processing of IdiA, an uncertainty remained concerning the translational start of $i d i A$. For this reason the $5^{\prime}$ region of $i d i A$ was again analysed. This additional sequencing provided evidence that from the previously published sequence (Michel et al., 1996) one nucleotide had to be omitted (2240). Evaluation of the newly determined $5^{\prime}$ terminal nucleotide region revealed that three ATG codons are in the correct reading frame, corresponding to positions 2121-2123 (Met-1), 21482150 (Met-10) and 2160-2162 (Met-14). Each could serve as initiator codon. Thus, it remains uncertain 
which of the three ATG codons might be the actual initiator codon for $i d i A$. Assuming that the first ATG is the initiator codon, then $i d i A$ would consist of $1101 \mathrm{bp}$ (start codon ATG at 2121 and stop codon TAA at 3221), encoding a protein of 366 aa with a calculated molecular mass $40167 \mathrm{Da}$ and an isoelectric point of 10.54 . If one of the other two ATG codons is the correct start codon, then a protein of $39035 \mathrm{Da}(\mathrm{pI} 10.68)$ or $38601 \mathrm{Da}(\mathrm{pI}$ $10.74)$, respectively, would result. In the new numbering system, based on the longest possible IdiA protein, the processing site of IdiA lies between Ala-45 and Ala-46. This cleavage site corresponds to a cleavage site as described for sll1725 from Synechocystis PCC 6803 by Sazuka \& Ohara (1996) (Proteome Project, Cyano$2 \mathrm{Dbase}$. However, the removed peptide of $5158 \mathrm{Da}$ does not possess the characteristic properties of a prokaryotic signal sequence according to the evaluation with PCGENE. Although the real translational start site of $i d i A$ remains uncertain, the presence of a possible assumed Shine-Dalgarno sequence at position 2104 (GGGG) would favour the first ATG codon in position 2121 as the most likely candidate. However, the GGGG sequence does not correspond to the three possible ribosome-binding sequences (GAGG, AGGA, GGAG) described for Synechocystis PCC 6803 by Sazuka \& Ohara (1996). There is a putative large hairpin of $35 \mathrm{bp}$ (3243-3277), in close proximity to the stop codon of idiA, that may terminate transcription of $i d i A$.

Besides showing homology to two bacterial Fe-binding proteins, SfuA from Serratia marcescens (Mietzner et al., 1987; Angerer et al., 1990) and FbpA from Neisseria sp. (Berish et al., 1990a, b) as previously reported (Michel et al., 1996), IdiA also shows homology to two ORFs from Synechocystis PCC 6803 (CyanoBase). These are $s l r 0513(52.02 \%$ identity and $9.83 \%$ conservative changes) and $\operatorname{slr} 1295(48.89 \%$ identity and $11.39 \%$ conservative changes) encoding proteins of $38155 \mathrm{Da}$ (pI 5.74) and $39370 \mathrm{Da}(\mathrm{pI} 4.63$ ), respectively. These two Synechocystis proteins have also been classified as Febinding proteins on the basis of their similarity to SfuA and FbpA.

\section{Transcript and primer extension analysis of idiA}

Fig. 3 shows the expression of IdiA at the protein level (Western blot) in comparison to mRNA expression (Northern blot). For these experiments Synechococcus PCC 6301 was grown in Fe-sufficient medium for $2 \mathrm{~d}$ and then cells were transferred into Fe-deficient medium $\left(60 \mu \mathrm{l} \mathrm{cells} \mathrm{ml}^{-1}\right)$, and grown for 2-4 d. Samples were taken at the times indicated in Fig. 3. For Western blot analysis the corresponding French press extracts of cell suspensions were used and for Northern blot analysis mRNA was extracted from cell suspensions. A $986 \mathrm{~kb}$ PCR idiA fragment labelled with DIG-dUTP or $\left[{ }^{32} \mathrm{P}\right] \mathrm{dATP}$ was used as a probe for identification of the $i d i A$ transcript. Hardly any $i d i A$ transcript was detectable in Synechococcus PCC 6301 cultures grown in Feand Mn-supplemented BG11 medium. The idiA tran- (a)

(b)

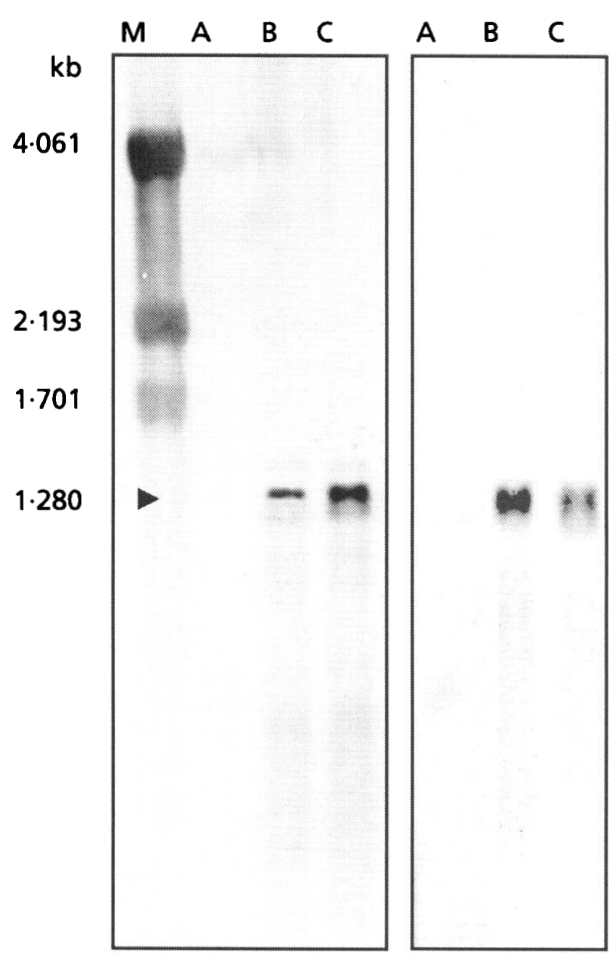

Fig. 4. Comparison of idiA transcript size in Synechococcus PCC 6301 (a) and PCC 7942 (b). Total RNA from the two strains was submitted to Northern blot analysis. The transcript size of the idiA mRNA corresponds to about $1300 \mathrm{nt}$. Lane $\mathrm{M}$, RNA markers. The position of the $1280 \mathrm{nt}$ fragment (barely visible) is marked by a triangle. In each of the lanes A-C, $10 \mu \mathrm{g}$ total RNA extracted from Synechococcus cells was applied. Lanes: A, RNA from cultures grown for $2 \mathrm{~d}$ under Fe-sufficient conditions; $B$, RNA from cultures grown for $2 \mathrm{~d}$ in medium with one-tenth of the regular Fe concentration; $C$, RNA from cultures grown for $2 \mathrm{~d}$ in medium without $\mathrm{Fe}$.

script was greatly enhanced when cells were exposed to Fe deficiency. Only one transcript of about $1300 \mathrm{nt}$ in length was detected, suggesting that $i d i A$ is transcribed monocistronically (Fig. 4). The high level of idiA transcript continued for at least $48 \mathrm{~h}$, but was significantly diminished after cells were exposed for more than $48 \mathrm{~h}$ to Fe-deficient growth. The results also show that synthesis of IdiA parallels synthesis of $i d i A$-specific mRNA, indicating that synthesis of IdiA starts without delay when the idiA-specific mRNA level goes up (Fig. 3). The high level of IdiA remains for at least $72 \mathrm{~h}$ growth under Fe deficiency (not shown), even though reduction of the idiA transcript was observed to have started after $48 \mathrm{~h}$ under the chosen growth conditions. Comparable results concerning IdiA expression at the transcriptional and translational level (not shown) and transcript size (Fig. 4) were also obtained with Synechococcus PCC 7942.

Primer extension analysis was undertaken to determine the transcriptional start and to possibly identify a promoter region upstream of $i d i A$ (Fig. 5) that should be 

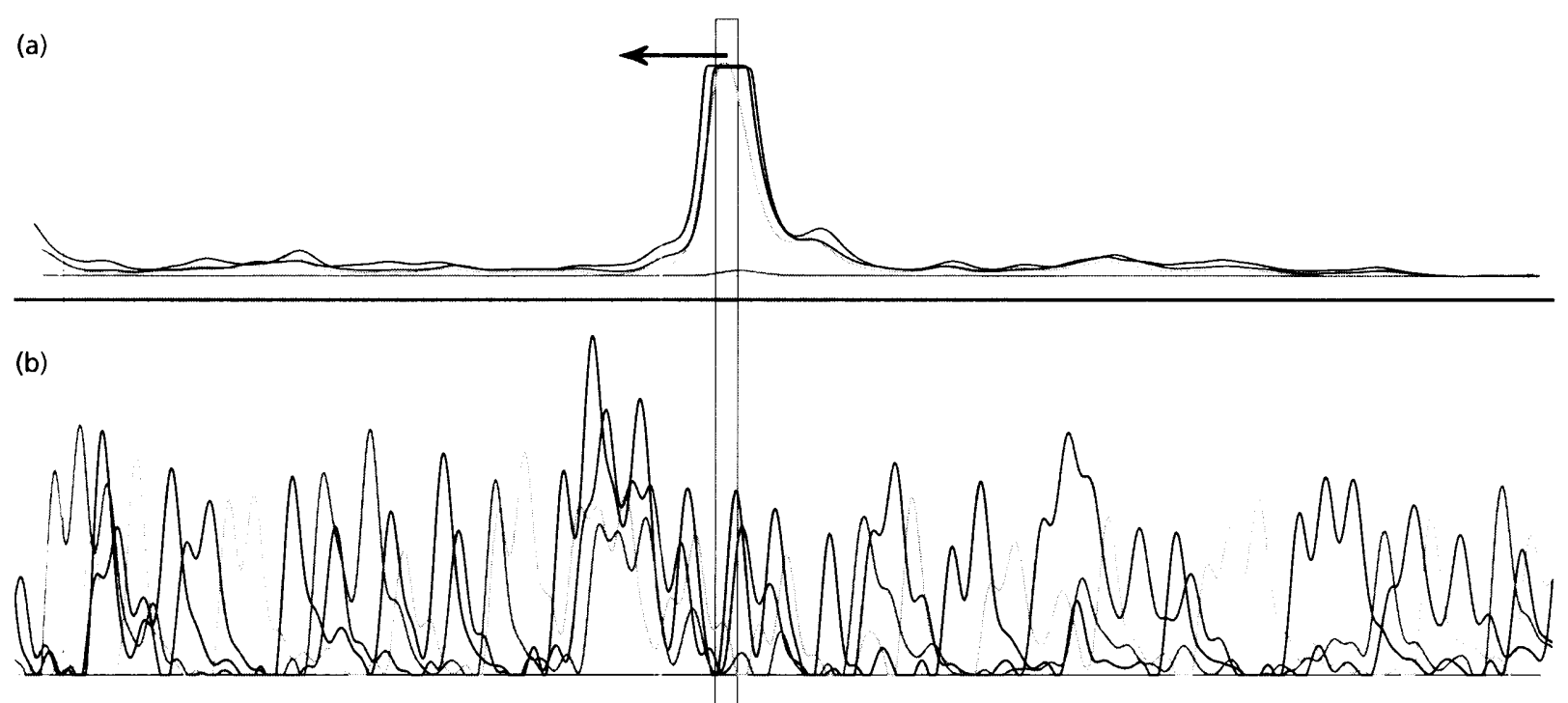

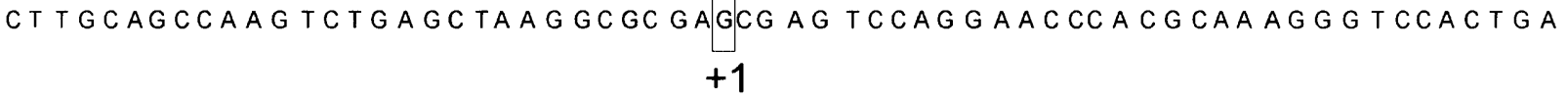

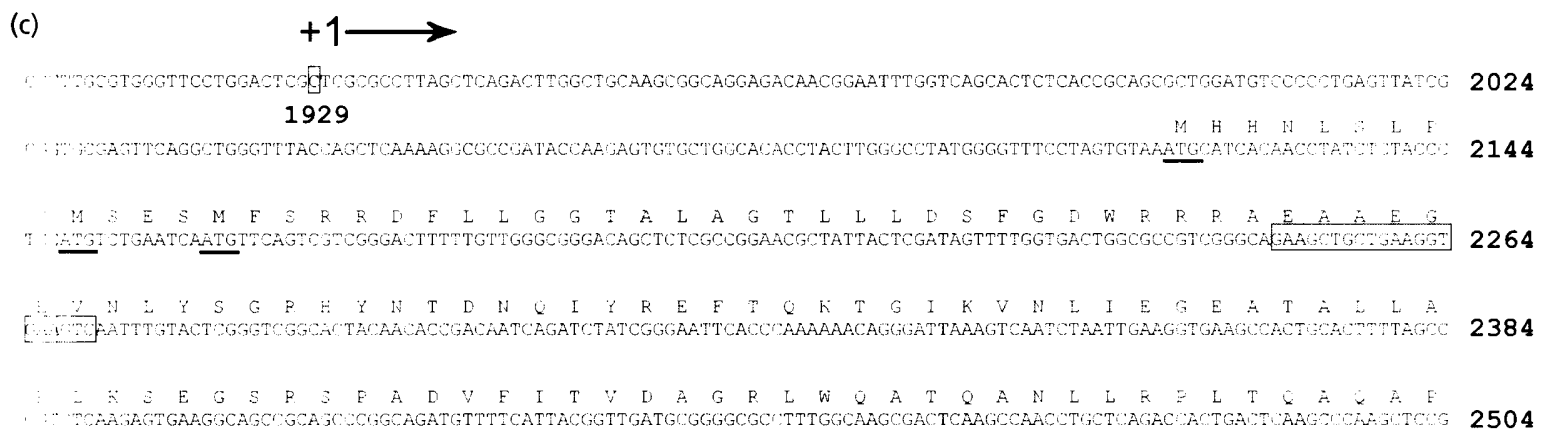

Fig. 5. Primer extension analysis of the primary transcript of idiA from Synechococcus PCC 6301. (a) Fluorogram obtained from a primer extension assay with Cy5'-labelled oligonucleotide primer KPM2 corresponding to positions 2270-2250 on pKPM24. The peak represents CDNA obtained after retrotranscription at $37^{\circ} \mathrm{C}$ for $1 \mathrm{~h}$. Annealing was carried out at 37,42 and $50^{\circ} \mathrm{C}$ for $2 \mathrm{~h}$. The arrow indicates the direction of transcription. The transcriptional start is marked with +1 . (b) DNA sequencing of the DNA region upstream of idiA was done with the same primer. The sequence represents the noncoding strand. (c) Partial nucleotide sequence of the idiA region between positions 1905 and 2504 . The first nucleotide is boxed and the forward arrow indicates the transcriptional start site and the direction of transcription. The three possible translational start codons of idiA are underlined. The position of primer KPM2 is boxed.

lying about $50 \mathrm{bp}$ in front of the transcriptional start (Curtis \& Martin, 1994). The sequence of the primers used was that of the non-coding strand. Four different primers (KPM2, KPM4, KPM5 and KPM6; see Methods) complementary to sequences downstream from the assumed translational start codon for idiA were successfully used. The experiments gave evidence that the transcriptional start lies at position 1929. Thus, the transcriptional start lies 193 bp before the assumed translational start (assuming the longest possible protein, i.e. ATG at position 2121). Based on primer extension analysis and on the assumption that the transcription ends at the hairpin at 3243-3277, the transcript of idiA from Synechococcus PCC 6301 consists of $1349 \mathrm{nt}$ and this value is in close agreement with the transcript size estimated from Northern blot analysis (about $1300 \mathrm{nt}$ for Synechococcus PCC 6301 and PCC 7942; Fig. 4). The DNA region upstream of the transcriptional start does not display nucleotide sequences similar to -10 or -35 promoter sequences of $E$. coli (Curtis \& Martin, 1994), nor to typical Fur-binding sequences (Straus, 1994). However, there is evidence that a likely Fur-binding sequence might be present in the $5^{\prime}$ untranslated region at position 1974-1992.

\section{Insertional inactivation of ORF2, ORF4 and ORF7 and preliminary characterization of the corresponding Synechococcus PCC 7942 mutants}

Synechococcus PCC 6301 and 7942 have been shown to be highly similar (Golden et al., 1989). However, since Synechococcus PCC 7942 is better than PCC 6301 for 
(a)

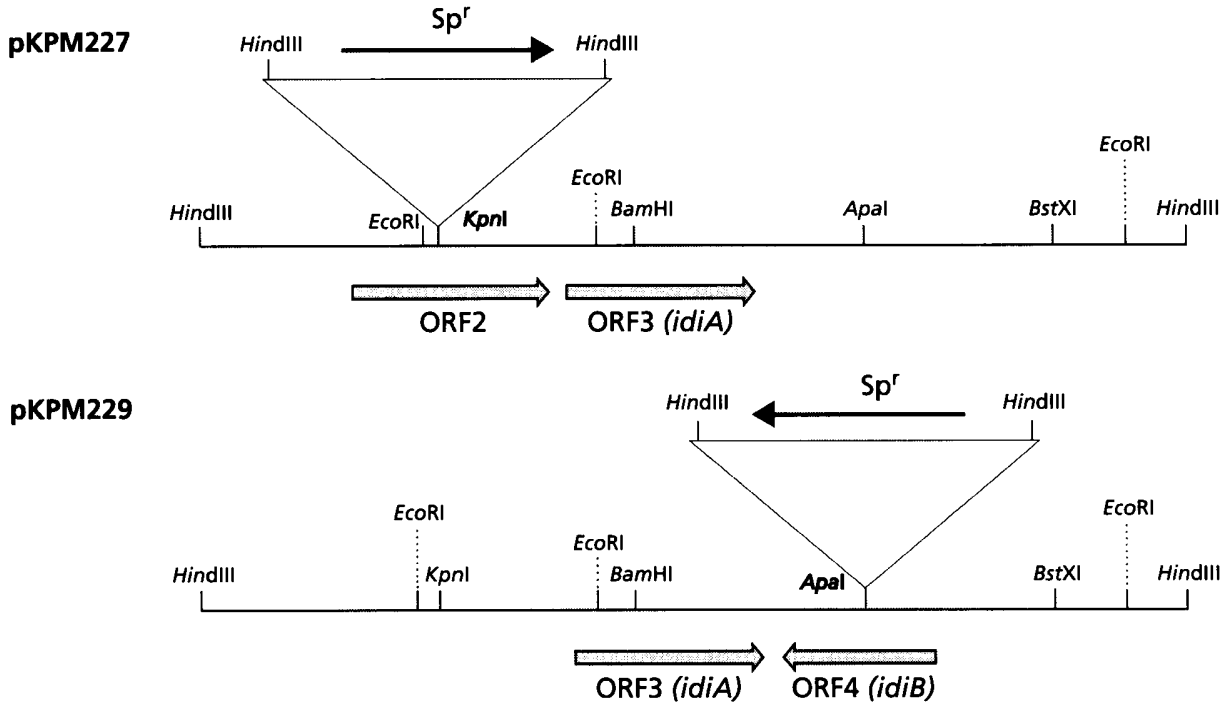

PKPM230

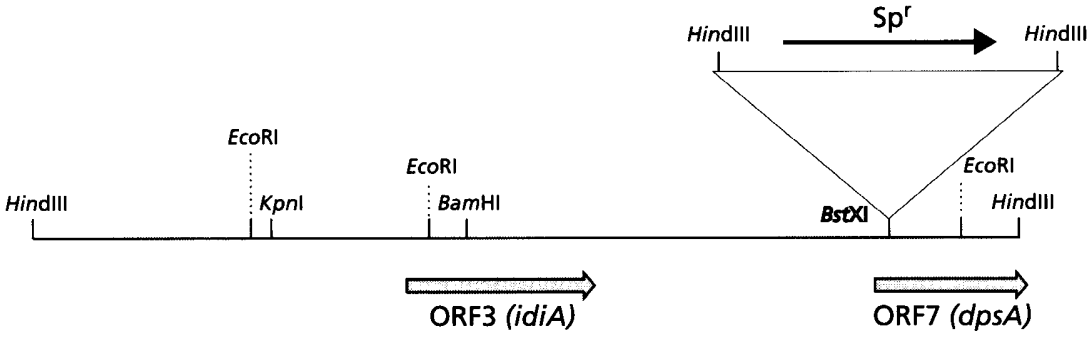

(b)

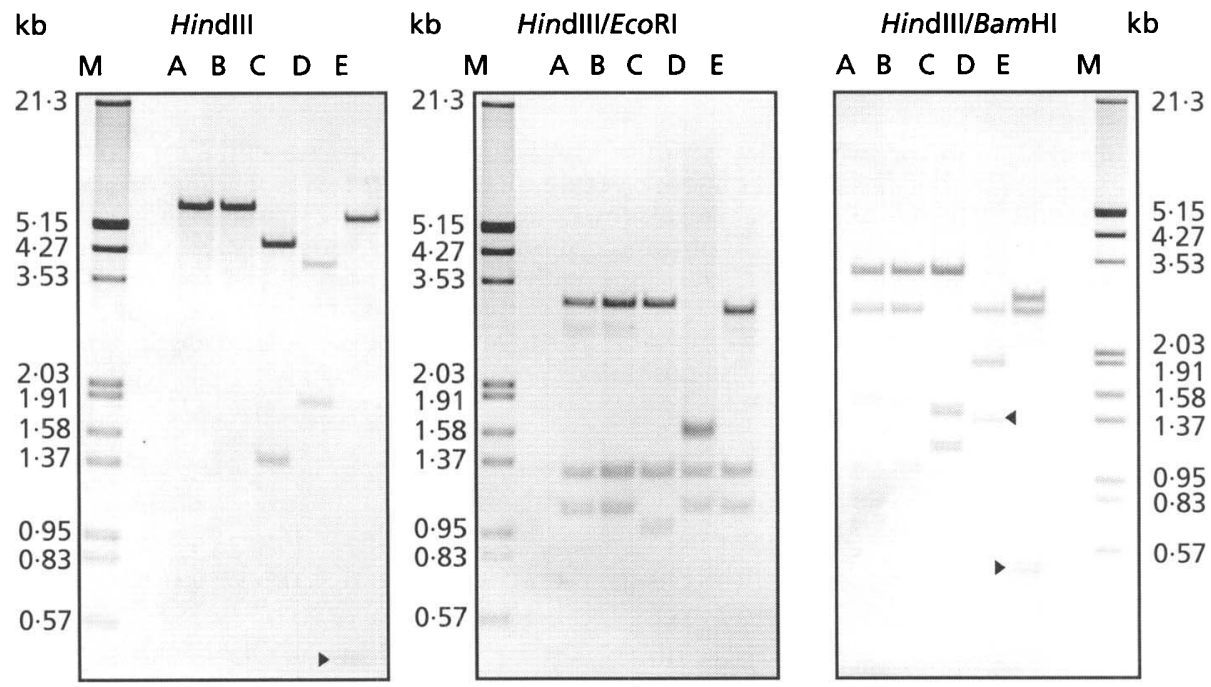

Fig. 6. Physical map of plasmids pKPM227, pKPM229 and pKPM230 used for construction of Synechococcus PCC 7942 mutants K9, K10 and K11 (a) and the corresponding Southern blots (b). All three plasmids are derivatives of plasmid pKPM24 and were constructed by insertion of a spectinomycin resistance cassette. The size and orientation of the three selected genes and the orientation of the resistance cassettes are shown by arrows. The restriction sites removed by insertion of the resistance cassette are indicated with outlined letters. The derived mutants were named Synechococcus PCC 7942 K9 (insertional inactivation of ORF2), K10 [insertional inactivation of ORF4 (idiB)] and K11 [insertional inactivation of ORF7 (dpsA)]. (b) Southern blots of genomic DNA from wild-type Synechococcus PCC 6301 (lane A) and PCC 7942 (B), and from Synechococcus PCC 7942 mutants K9 (C), K10 (D) and K11 (E) digested with HindIII, HindIII/EcoRI or HindIII/BamHI as indicated. DNA was detected with the DIG-labelled $5.8 \mathrm{~kb}$ HindIII insert from pKPM24. The DNA fragments obtained with all three restriction enzyme combinations are identical for Synechococcus PCC 6301 and PCC 7942. Lanes M, DIG-labelled DNA markers III (Boehringer Mannheim). 
Table 1. Growth, pigment content and photosynthetic activities of Synechococcus PCC 7942

Cells were grown in Fe-sufficient $(+\mathrm{Fe})$ or Fe-deficient $(-\mathrm{Fe})$ medium under standard conditions. After $2 \mathrm{~d}$ growth, cells were harvested, resuspended in $50 \mathrm{mM}$ HEPES/ $\mathrm{NaOH}, \mathrm{pH} 6 \cdot 5$, containing $50 \mathrm{mM} \mathrm{CaCl}_{2}$ and $400 \mathrm{mM}$ sucrose, to give a cell density of

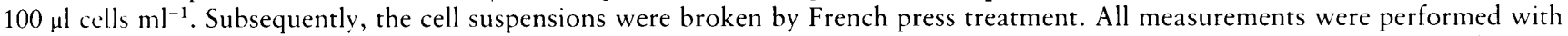
this French press extract (FPE). Details are given in Methods. The data are representative of three to five independent growth experiments.

\begin{tabular}{|c|c|c|c|c|c|c|c|}
\hline Strain & Medium & $\begin{array}{l}\text { Growth } \\
\left(\mathrm{OD}_{7 \mathbf{7 5}}\right)\end{array}$ & $\begin{array}{c}\text { Chlorophyll } \\
{\left[\mathrm{mg}(\mathrm{ml} \mathrm{FPE})^{-1}\right]}\end{array}$ & $\begin{array}{l}\text { Phycocyanin } \\
{\left[\mathrm{mg}(\mathrm{ml} \mathrm{FPE})^{-1}\right]}\end{array}$ & $\begin{array}{l}\text { Allophycocyanin } \\
{\left[\mathrm{mg}(\mathrm{ml} \mathrm{FPE})^{-1}\right]}\end{array}$ & $\begin{array}{c}\text { PS II activity } \\
{[\mu \mathrm{mol} \mathrm{O}} \\
\text { evolved } \\
\left.(\mathrm{mg} \mathrm{Chl})^{-1} \mathrm{~h}^{-1}\right]\end{array}$ & $\begin{array}{c}\text { PS I activity } \\
{\left[\boldsymbol{\mu} \text { mol } \mathrm{O}_{2}\right.} \\
\text { consumed } \\
\left.(\mathrm{mg} \mathrm{Chl})^{-1} \mathrm{~h}^{1}\right]\end{array}$ \\
\hline \multirow[t]{2}{*}{ Wild-type } & $+\mathrm{Fe}$ & $2 \cdot 3$ & $0 \cdot 72$ & $4 \cdot 8$ & 2.5 & 127 & 124 \\
\hline & $-\mathrm{Fe}$ & 1.6 & $0 \cdot 41$ & $2 \cdot 9$ & $2 \cdot 1$ & 108 & 123 \\
\hline \multirow{2}{*}{ Mutant $14(\nabla$ ORF3 $=$ Vidi $A)$} & $+\mathrm{Fe}$ & 1.4 & 0.33 & $2 \cdot 4$ & 1.5 & 79 & 133 \\
\hline & $-\mathrm{Fe}$ & $0 \cdot 4$ & $0 \cdot 21$ & $1 \cdot 8$ & $1 \cdot 3$ & 21 & 124 \\
\hline \multirow[t]{2}{*}{ Mutant K9 (DORF2) } & $+\mathrm{Fe}$ & $2 \cdot 3$ & $0 \cdot 62$ & $4 \cdot 3$ & $1 \cdot 8$ & 104 & 102 \\
\hline & $-\mathrm{Fe}$ & $1 \cdot 4$ & $0 \cdot 39$ & $2 \cdot 6$ & $1 \cdot 4$ & 86 & 112 \\
\hline \multirow{2}{*}{ Mutant $\mathrm{K} 10($ DORF4 $=\nabla i d i B)$} & $+\mathrm{Fe}$ & $2 \cdot 3$ & $0 \cdot 66$ & $4 \cdot 1$ & $2 \cdot 5$ & 102 & 73 \\
\hline & $-\mathrm{Fe}$ & 1.7 & $0 \cdot 29$ & $0 \cdot 8$ & $0 \cdot 6$ & 75 & 74 \\
\hline \multirow[t]{2}{*}{ Mutant K11 $(\nabla$ ORF7 $=\nabla d p s A)$} & $+\mathrm{Fe}$ & $2 \cdot 3$ & 0.66 & $4 \cdot 7$ & $3 \cdot 1$ & 104 & 131 \\
\hline & $-\mathrm{Fe}$ & $1 \cdot 6$ & $0 \cdot 45$ & $2 \cdot 0$ & $3 \cdot 4$ & 47 & 152 \\
\hline
\end{tabular}

transformation, we utilized strain PCC 7942 for mutant studies, as in a previous paper (Michel et al., 1996). The comparative restriction analysis of the respective DNA region in Synechococcus PCC 6301 and 7942 is presented in Fig. 6(b), showing that on this basis no differences in this DNA region could be detected between these two Synechococcus strains.

For mutant studies, ORF2 (located immediately upstream of idiA), ORF4 (idiB-located immediately downstream of $i d i A$ ) and ORF7 (dpsA - located 2018 bp downstream of $i d i A$ ) were interrupted by insertion of a spectinomycin resistance cassette (Fig. 6a). In all three cases the resistance cassette was in the same orientation as the corresponding gene. Transformation of Synechococcus PCC 7942 cells with the corresponding plasmids pKPM227, pKPM229 or pKPM230 (see Methods and Fig. 6a) resulted in $S p^{R}$ and $A p^{S}$ transformants, implying that the desired double recombination event had occurred. This was verified by Southern analysis (Fig. 6b). The ohtained mutants were called Synechococcus PCC $7942 \mathrm{~K} 9$ (inactivation of ORF2), K10 [inactivation of ORF4 (idiB)] and K11 [inactivation of ORF7 $(d p s A)$ ].

Comparative analysis of the three Synechococcus mutants with the wild-type showed that there was no significant reduction in growth of the mutants in comparison to the wild-type when cells were grown for $48 \mathrm{~h}$ in Fe-sufficient or Fe-deficient medium, while the previously constructed IdiA-free mutant, Synechococcus PCC 7942 I4 (Michel et al., 1996), showed significant reduction in growth under the latter conditions (Table 1). On the basis of tested parameters, mutant $K 9$ did not significantly deviate from the wild-type in contrast to mutants $\mathrm{K} 10$ and K11. Comparative Western blot analysis with anti-IdiA antiserum gave clear evidence that in mutants K10 and K11 lacking IdiB or DpsA, respectively, the expression of IdiA was greatly reduced compared to wild-type cells, an observation most clearly seen under Fe deficiency (Fig. 7). As expected, PS II activity in mutants $\mathrm{K} 10$ and $\mathrm{K} 11$ was lower than in wildtype cells but not as low as in the completely IdiA-free mutant I4. Absence of IdiB under Fe-deficient conditions led to a significantly higher reduction of chlorophyll, phycocyanin and allophycocyanin, and also to a reduction of PS I activity in addition to a reduction of PS II activity compared to wild-type cells. In contrast, the absence of DpsA led only to a minor deviation of chlorophyll and phycocyanin content in comparison to wild-type but caused a significant increase in the allophycocyanin content. Moreover, PS I activity remained very stable under Fe-deficient growth conditions. Obviously, in mutant $\mathrm{K} 11$ the large reduction of PS II activity under Fe deficiency, in part due to the reduced IdiA level, is compensated by alterations in the pigment content and by a process leading to stabilization of PS I (Table 1). As a consequence, this mutant can grow quite well under mild Fe deficiency in contrast to the completely IdiA-free mutant 14 with a greatly reduced pigment content under Fe deficiency.

\section{Concluding remarks}

Analysis of the DNA region close to $i d i A$ revealed that in the region downstream of $i d i A$ two genes (idiB and $d p s A$ ) are located whose gene products function either directly or indirectly in activating IdiA expression. A direct regulation of IdiA expression on transcriptional level due to binding of these two proteins to the promoter region of $i d i A$ seems likely since IdiB has similarity to DNA-binding proteins with a helixturn-helix and a SPXX motif, typical for this type of transcriptional factor (see Fig. 2), and DpsA belongs to a group of stress-induced polypeptides that presumably bind DNA as stated by Pena \& Bullerjahn (1995). This 
(a)

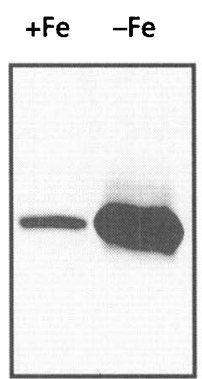

(b)

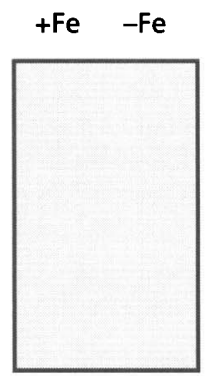

(c)

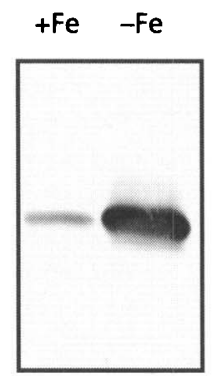

(d)

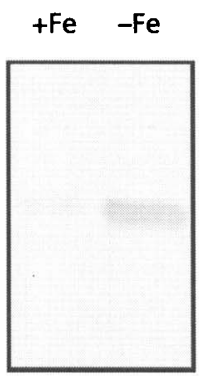

(e)

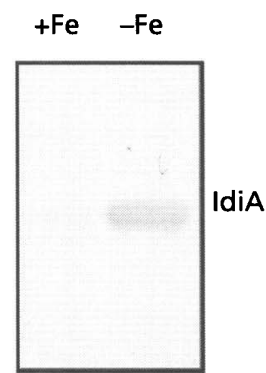

Fig. 7. Analysis of IdiA protein expression in Synechococcus PCC 7942 wild-type (a) and mutants K9 (c; קORF2), K10 (d; DORF4) and K11 (e; VORF7). Cultures were grown for $2 \mathrm{~d}$ in Fe-sufficient (+Fe) or Fe-deficient ( $-\mathrm{Fe}$ ) medium. The previously constructed mutant 14 (b; completely IdiA-free) is included for comparison. After preparation of French press extracts (see legend to Table 1), samples were submitted to SDS-PAGE and after transfer of proteins to nitrocellulose immunostaining was performed with the anti-IdiA antiserum.

implies that regulation of IdiA expression is rather complex. Whether IdiA expression is additionally regulated by the Fur protein, shown to be also present in Synechococcus PCC 7942 (Ghassemian \& Straus, 1996), is presently unknown. A likely Fur-binding consensus sequence (see Straus, 1994), with 11/19 nt similar to this sequence, lies in the $5^{\prime}$ untranslated region of $i d i A$ (see also Vinnemeier et al., 1998).

It should also be pointed out that although IdiB and DpsA are functional in activating IdiA expression, these presumed DNA-binding proteins seem to have a regulatory function, not only on IdiA expression but also on expression of other photosynthesis-related proteins. The phenotype of mutants $\mathrm{K} 10$ and $\mathrm{K} 11$ are similar with respect to the reduced IdiA expression under Fe deficiency leading to reduced PS II activity, but differ in pigment content and PS I activity (see above).

IdiA has homology to two bacterial Fe-binding proteins, SfuA and FbpA, that function as the periplasmic-binding protein component of a high-affinity transporter $(A B C$ type) for Fe from human transferrin (Chen et al., 1993; Adhikari et al., 1996; Forng et al., 1997). In contrast to these proteins, IdiA is located intracellularly, mainly associated with the cytoplasmic side of the thylakoid membrane (Michel et al., 1998). Thus in spite of some similarity to SfuA and $\mathrm{FbpA}$, neither the cellular location nor the neighbouring genes suggest that IdiA is part of a classical periplasmic $\mathrm{ABC}$ transporter for $\mathrm{Fe}$. On the basis of the available data, it can be concluded that the main function of IdiA is in protecting and/or optimizing PS II activity under nutrient deficiency. The complex regulation of IdiA expression emphasizes the importance of IdiA in optimizing PS II activity. Because of its similarity to bacterial $\mathrm{Fe}$ - (and $\mathrm{Mn}$-) binding proteins and its location on the cytoplasmic side of the thylakoid membrane, IdiA might function either as a Fe-binding protein that specifically provides PS II with the $\mathrm{Fe}$ located on the acceptor side (Askwith \& Kaplan, 1998; Merchant \& Dreyfuss, 1998) or it might be a component of a $\mathrm{Mn}$ transporter via the thylakoid membrane. Although the complex compensating reactions occur- ring in the photosynthetic reaction centres and in the pigment complexes in response to Fe deficiency are far from fully understood, it is quite obvious that the chlorophyll-protein complex CPVI-4 (containing a CP43 homologue protein, IsiA) (Riethman \& Sherman, 1988a, b; Laudenbach \& Straus 1988; Burnap et al., 1993) and, as our results show, IdiA have an important function in this process.

\section{ACKNOWLEDGEMENTS}

The financial support of the Deutsche Forschungsgemeinschaft is gratefully acknowledged. We also thank Drs Anke Becker, Helge Küster and Andreas Perlick for helpful suggestions and critical discussions.

\section{REFERENCES}

Adhikari, P., Berish, S. A., Nowalk, A. J., Veraldi, K. L., Morse, S. A. \& Mietzner, T. A. (1996). The $f b p A B C$ locus of Neisseria gonorrboeae functions in the periplasm-to-cytosol transport of iron. J Bacteriol 178, 2145-2149.

Altschul, S. F., Gish, W., Miller, W., Myers, E. W. \& Lipman, D. J. (1990). Basic local alignment search tool. J Mol Biol 215, 403-410.

Angerer, A., Gaisser, S. \& Braun, V. (1990). Nucleotide sequences of the $s f u A, s f u B$, and $s f u C$ genes of Serratia marcescens suggest a periplasmic-binding-protein dependent iron transport mechanism. J Bacteriol 172, 572-578.

Arnold, W. \& Pühler, A. (1988). A family of high-copy-number plasmid vectors with single end-label sites for rapid nucleotide sequencing. Gene 70, 171-179.

Askwith, C. \& Kaplan, J. (1998). Iron and copper transport in yeast and its relevance to human disease. Trends Biochem Sci 23, 135-138.

Bartsevich, V. V. \& Pakrasi, H. B. (1995). Molecular identification of an $\mathrm{ABC}$ transporter complex for manganese: analysis of a cyanobacterial mutant strain impaired in the photosynthetic oxygen evolution process. EMBO J 14, 1845-1853.

Bartsevich, V. V. \& Pakrasi, H. B. (1996). Manganese transport in the cyanobacterium Synechocystis sp. PCC 6803. J Biol Chem 271, 26057-26061.

Batut, J., Daveran-Mongot, M. I., David, M., Jacobs, J., Garnerone, A. M. \& Kahn, D. (1989). fixK, a gene homologous with $f n r$ 
and $c r p$ from Escherichia coli, regulates nitrogen fixation genes both positively and negatively in Rhizobium meliloti. EMBO J 8, 1279-1286.

Berish, S. A., Mietzner, T. A., Mayer, L. W., Genco, C. A., Holloway, B. P. \& Morse, S. A. (1990a). Molecular cloning and characterization of the structural gene for the major ironregulated protein expressed by Neisseria gonorrhoeae. J Exp Med $171,15.35-1546$.

Berish, S. A., Kapczynski, D. R. \& Morse, S. A. (1990b). Nucleotide sequence of the Fbp gene from Neisseria meningitidis. Nucleic Acids Res 18, 4596.

Bradley, R. L. \& Reddy, K. J. (1997). Cloning, sequencing, and regulation of the global nitrogen regulator gene $n t c A$ in the unicellular diazotrophic cyanobacterium Cyanothece sp. strain BH68K. I Bacteriol 179, 4407-4410.

Brennan, R. G. \& Matthews, B. W. (1989). The helix-turn-helix DNA binding motif. J Biol Chem 264, 1903-1906.

Burnap, R. L., Troyan, T. \& Sherman, L. A. (1993). The highly abundant chlorophyll-protein complex of iron-deficient Synechococcus sp. PCC 7942 (CP43') is encoded by the isiA gene. Plant Physiol 103, 893-902.

Carr, H. G. \& Mann, N. H. (1994). The oceanic cyanobacterial picoplankton. In The Molecular Biology of Cyanobacteria, pp. 27-48. Edited by D. A. Bryant. Dordrecht, Boston \& London: Kluwer Academic Publishers.

Chen, C.-Y., Berish, S. A., Morse, S. A. \& Mietzner, T. A. (1993). The ferric iron-binding protein of pathogenic Neisseria spp. functions as a periplasmic transport protein in iron acquisition from human transferrin. Mol Microbiol 10, 311-318.

Curtis, S. E. \& Martin, J. A. (1994). Transcription in cyanobacteria. In The Molecular Biology of Cyanobacteria, pp. 731-750. Edited by D. A. Bryant. Dordrecht, Boston \& London: Kluwer Academic Puhlishers.

Debus, R. J. (1992). The manganese and calcium ions of photosynthetic oxygen evolution. Biochim Biophys Acta 1102, 269-352.

Fellay, R., Frey, J. \& Krisch, H. (1987). Interposon mutagenesis of soil and water bacteria : a family of DNA fragments designed for in vitro insertional mutagenesis of gram-negative bacteria. Gene 52, 147-154.

Ferreira, F. \& Straus, N. A. (1994). Iron deprivation in cyanobacteria. J Appl Phycol 6, 199-210.

Forng, R.-Y., Ekechukwu, C. R., Subbarao, S., Morse, S. A. \& Genco, C. A. (1997). Promoter mapping and transcriptional regulation of the iron-regulated Neisseria gonorrhoeae $f b p A$ gene. J Bacteriol 179, 3047-3052.

Frias, J. E., Merida, A., Herrero, A., Martin-Nieto, J. M. \& Flores, E. (1993). General distribution of the nitrogen control gene $n t c A$ in cyanobacteria. J Bacteriol 175, 5710-5713.

Ghassemian, M. \& Straus, N. A. (1996). Fur regulates the expression of iron-stress genes in the cyanobacterium Synechococcus sp. strain PCC 7942. Microbiology 142, 1469-1476.

Golden, S. S., Nalty, M. S. \& Cho, D.-S. C. (1989). Genetic relationship of two highly studied Synechococcus strains designated Anacystis nidulans. J Bacteriol 171, 24-29.

Grant, S. G. N., Jessee, J., Bloom, F. G. \& Hanahan, D. (1990). Differential plasmid rescue from transgenic mouse DNAs in Escherichia coli methylation restriction mutants. Proc Natl Acad Sci USA 87, 4645-4649.

Grimme, L. H. \& Boardman, N. K. (1972). Photochemical activation of a particle fraction P1 obtained from the green alga Chlorella fusca. Biochem Biophys Res Commun 49, 1617-1623.
Hoshino, T. \& Kose, K. (1990). Cloning, nucleotide sequence, and identification of products of the Pseudomonas aeruginosa $\mathrm{PAO}$ bra genes, which encode the high-affinity branched-chain amino acid transport system. J Bacteriol 172, 5531-5539.

Katzen, F., Becker, A., Zorreguieta, A., Pühler, A. \& lelpi, L. (1996). Promoter analysis of the Xanthomonas campestris pv. campestris gum operon directing biosynthesis of the xanthan polysaccharide. J Bacteriol 178, 4313-4318.

Kratz, W. A. \& Myers, J. (1955). Nutrition and growth of several blue-green algae. Am J Bot 42, 282-287.

Laemmli, U. K. (1970). Cleavage of structural proteins during the assembly of the head of bacteriophage T4. Nature 227, 680-685.

Landick, R. \& Oxender, D. W. (1985). The complete nucleotide sequence of the Escherichia coli LIV-BP and LS-BP genes. J Biol Chem 260, 8257-8261.

Laudenbach, D. E. \& Straus, N. A. (1988). Characterization of a cyanobacterial iron stress-induced gene similar to $p s b C$. $J$ Bacteriol 170, 5018-5026.

Leonhardt, K. \& Straus, N. A. (1992). An iron stress operon involved in photosynthetic electron transport in the marine cyanobacterium Synechococcus sp. PCC 7002. J Gen Microbiol 138, 1613-1621.

Leonhardt, K. \& Straus, N. A. (1994). Photosystem II genes isiA, $p s b D I$ and $p s b C$ in Anabaena sp. PCC 7120 : cloning, sequencing and the transcriptional regulation in iron-stressed and ironreplete cells. Plant Mol Biol 24, 63-73.

Merchant, S. \& Dreyfuss, B. W. (1998). Posttranslational assembly of photosynthetic metalloproteins. Annu Rev Plant Physiol Plant Mol Biol 49, 25-51.

Michel, K.-P. \& Pistorius, E. K. (1992). Isolation of a photosystem II associated $36 \mathrm{kDa}$ polypeptide and an iron stress $34 \mathrm{kDa}$ polypeptide from thylakoid membranes of the cyanobacterium Synechococcus PCC 6301 grown under mild iron deficiency. Z Naturforsch 47c, 867-874.

Michel, K.-P., Thole, H. H. \& Pistorius, E. K. (1996). IdiA, a 34 kDa protein in the cyanobacterium Synechococcus sp. strains PCC 6301 and PCC 7942, is required for growth under iron and manganese limitations. Microbiology 142, 2635-2645.

Michel, K.-P., Exss-Sonne, P., Scholten-Beck, G., Kahmann, U., Ruppel, H. G. \& Pistorius, E. K. (1998). Immunocytochemical localization of IdiA, a protein expressed under iron or manganese limitation in the mesophilic cyanobacterium Synechococcus PCC 6301 and the thermophilic cyanobacterium Synechococcus elongatus. Planta 205, 73-81.

Mietzner, T. A., Bolan, G., Schoolnik, G. \& Morse, S. A. (1987). Purification and characterization of the major iron-regulated protein expressed by pathogenic Neisseriae. J Exp Med 165, 1041-1057.

Nazos, P., Antonucci, T. K., Landick, R. \& Oxender, D. L. (1986). Cloning and characterization of $l i v H$, the structural gene encoding a component of the leucine transport system in Escherichia coli. J Bacteriol 166, 565-573.

Nicholson, M. L. \& Laudenbach, D. E. (1995). Genes encoded on a cyanobacterial plasmid are transcriptionally regulated by sulfur availability and CysR. J Bacteriol 177, 2143-2150.

Pastan, I. \& Adhya, S. (1976). Cyclic adenosine 5'-monophosphate in Escherichia coli. Bacteriol Rev 40, 527-551.

Pena, M. M. O. \& Bullerjahn, G. S. (1995). The DpsA protein of Synechococcus sp. strain PCC 7942 is a DNA-binding hemoprotein. J Biol Chem 270, 22478-22482. 
Pistorius, E. K., Kertsch, R. \& Faby, S. (1989). Investigations about various possible functions of the L-amino acid oxidase in the cyanobacterium Anacystis nidulans. Z Naturforsch 44c, 370-377.

Reddy, K. J., Bullerjahn, G. S., Sherman, D. M. \& Sherman, L. A. (1988). Cloning, nucleotide sequence, and mutagenesis of a gene (irpA) involved in iron-deficient growth of the cyanobacterium Synechococcus sp. strain PCC 7942. J Bacteriol 170, 4466-4476.

Reddy, K. J., Webb, R. \& Sherman, L. A. (1990). Bacterial RNA isolation with one hour centrifugation in a table-top ultracentrifuge. Biotechniques 8, 250-251.

Riethman, H. C. \& Sherman, L. A. (1988a). Immunological characterization of iron-regulated membrane proteins in the cyanobacterium Anacystis nidulans R2. Plant Physiol 88, 497-505.

Riethman, H. C. \& Sherman, L. A. (1988b). Purification and characterization of an iron stress-induced chlorophyll-protein from the cyanobacterium Anacystis nidulans R2. Biochim Biophys Acta 935, 141-151.

Rippka, R. (1988). Isolation and purification of cyanobacteria. Methods Enzymol 167, 3-27.

Rychlik, W. \& Rhoads, R. E. (1989). A computer program for choosing optimal oligonucleotides for filter hybridization, sequencing and in vitro amplification of DNA. Nucleic Acid Res 17, 8543-8551.

Sambrook, J., Fritsch, E. F. \& Maniatis, T. (1989). Molecular Cloning: a Laboratory Manual, 2nd edn. Cold Spring Harbor, NY: Cold Spring Harbor Laboratory.

Sazuka, T. \& Ohara, O. (1996). Sequence features surrounding the translation initiation sites assigned on the genome sequence of Synechocystis sp. strain PCC 6803 by amino-terminal protein sequencing. DNA Res 3, 225-232.

Schägger, H. \& von Jagow, G. (1987). Tricine-sodium dodecylsulfate-polyacrylamide gel electrophoresis for the separation of proteins in the range from 1 to $100 \mathrm{kDa}$. Anal Biochem $\mathbf{1 6 6}$, 368-379.

Smith, P. K., Krohn, R. I., Hermanson, G. T. \& 7 other authors (1985). Measurement of protein using bicinchoninic acid. Anal Biochem 150, 76-85.

Staden, R. (1986). The current status and portability of our sequence handling software. Nucleic Acids Res 14, 217-232.

Straus, N. A. (1994). Iron deprivation: physiology and gene regulation. In The Molecular Biology of Cyanobacteria, pp. 731-750. Edited by D. A. Bryant. Dordrecht, Boston \& London : Kluwer Academic Publishers.

Suzuki, K., Sagai, H., Imamura, S. \& Sugiyama, M. (1994). Cloning, sequencing, and overexpression in Escherichia coli of a sarcosine oxidase-encoding gene linked to the Bacillus creatinase gene. J Ferment Bioeng 77, 231-234.

Suzuki, M. (1989). SPXX, a frequent sequence motif in gene regulatory proteins. $J \mathrm{Mol}$ Biol 207, 61-84.

Tandeau de Marsac, N. \& Houmard, J. (1988). Complementary chromatic adaptation: Physiological conditions and action spectra. Methods Enzymol 167, 318-328.

Unden, G. \& Guest, R. J. (1985). Isolation and characterization of the FNR protein, the transcriptional regulator of anaerobic electron transport. Eur J Biochem 146, 193-199.

Vega-Palas, M. A., Flores, E. \& Herrero, A. (1992). Nitrate assimilation gene cluster from the heterocyst-forming cyanobacterium Anabaena sp. strain PCC 7120. J Bacteriol 179, $477-486$.

Vinnemeier, J., Kunert, A. \& Hagemann, M. (1998). Transcriptional analysis of the $i s i A B$ operon in salt-stressed cells of the cyanobacterium Synechocystis sp. PCC 6803. FEMS Microbiol Lett 169, 323-330.

Webb, R., Troyan, T., Sherman, D. \& Sherman, L. A. (1994). MapA, an iron-regulated, cytoplasmic membrane protein in the cyanobacterium Synechococcus sp. strain PCC 7942. J Bacteriol 176, 4906-4913.

Wei, T.-F., Ramasubramanian, T. S., Pu, F. \& Golden, J. W. (1993). Anabaena sp. strain PCC 7120 ntcA gene required for growth on nitrate and heterocyst development. J Bacteriol 176, 4473-4482.

Wierenga, R. K., Terpstra, P. \& Hol, W. G. J. (1986). Prediction of the occurrence of the ADP-binding $\beta \alpha \beta$-fold in proteins, using an amino acid sequence fingerprint. J Mol Biol 187, 101-107.

William, J. G. K. (1988). Construction of specific mutants in photosystem II photosynthetic reaction centre by genetic engineering methods in Synechocystis PCC 6803. Methods Enzymol $167,766-778$.

Received 2 November 1998; revised 11 January 1999; accepted 25 February 1999. 